\title{
Investigation of Dependence of Microstructural Changes of Aluminum Alloy 2024-T3 Taking into Account the Type of Preliminary Load
}

\author{
Volodymyr HUTSAYLYUK ${ }^{1}$ \\ ${ }^{1}$ Institute Robots and Machine Design, Faculty Mechanical Engineering, Military University of Technology, Gen. \\ Sylwestra Kaliskiego 2 str., 00-908 Warsaw, Poland \\ E-mail: ${ }^{1}$ volodymyr.hutsaylyuk@wat.edu.pl
}

\begin{abstract}
The article presents the results of the study of the effect of combined preload on the change of mechanical properties of the aluminum alloy 2024-T3 at room temperature. The disclosure changes in the mechanical properties of the alloy were explained during the analysis of the deformation process in the material at the micro level (material grain). Experimental studies of the deformation process and its implementation mechanism at the micro level were carried out using the thin foil method using a Hitachi STEM HD2700 transmission electron microscope. Electron microscopic examination of the foil revealed an inclusion of minor phase particles in the aluminum matrix, which create a noticeable contrast in the image - dark inclusions against the background of the light matrix. The change of the dislocation density after combined loading was also found, because the scalar density of the dislocation in the material is in this case lower than after the tensile test, despite the same residual plastic deformation of the samples.
\end{abstract}

KEY WORDS: 2024-T3 aluminum alloy, combined load, thin foil method, scalar dislocation density

\section{Introduction}

In real service conditions of engineering structures and its components are exposed to various external loads. Usually, in most calculation methods of metal structures, is assumed to determine strength of the structure including the preliminary load. However, this approach does not fully use even in the case of summation of the actions of one type of load. It refers to the impact additional force impulse at strength of the material during the monotonic tension [1].

Observed initiation non-equilibrium dynamic processes leading to adaptation of the material for a new conditional equilibrium depending on the value of the additional force impulse and the conditions of its implementation. Internal equilibrium is possible only by absorbing the outside total energy by the material. It leads to a formation of a new ordered structure (material state), so-called dissipative structure. From the energy point of view the best situation is to create the dissipative structure in a specified volume of material. The newly formed structure (material state) causes changes in the mechanical properties of the material compared to its initial state [2-5]. Immediate failure of the sample occurs when the material is not able to absorb the external energy, although the overall load is below the permissible level. Authors of papers $[6,7]$ involve changes in the structure of the material on dynamic non-equilibrium processes with significant fluctuations in supply of energy to the sample material at high speeds of deformation, resulting in a sample material is still in an activated state. Energy dissipation occurs in the local weak zones. Previously performed a study on changes of mechanical properties of the material identified during monotonic tension [7,8] allow for quantification of the impact of dynamic non-equilibrium processes occurring during the implementation an additional force impulse. Still, unclear is the physical nature of this phenomenon. There is a lack of fractographic research aimed at determining mechanisms of structural changes at the micro level during the implementation of a given type of load. In the present work the author attempted to clarify the mechanism of structural changes based on fractographic analysis.

\section{Material and Test Procedure}

The material used in tests was 2024-T3 Alclad aluminium alloy as supplied. According to the manufacturer its chemical composition and mechanical properties are given in Table 1.

\footnotetext{
${ }^{1}$ Corresponding author.

E-mail address: volodymyr.hutsaylyuk@wat.edu.pl
} 
Table 1

Chemical composition and mechanical properties 2024-T3 aluminium alloy

\begin{tabular}{|c|c|c|c|c|c|c|c|}
\hline \multicolumn{7}{|c|}{ Chemical composition [\%] } \\
\hline $\mathrm{Si}$ & $\mathrm{Fe}$ & $\mathrm{Cu}$ & $\mathrm{Mn}$ & $\mathrm{Mg}$ & $\mathrm{Cr}$ & $\mathrm{Zn}$ & $\mathrm{Ti}$ \\
\hline 0,05 & 0,13 & 4,7 & 0,70 & 1,5 & $0,01<$ & 0,02 & 0,04 \\
\hline \multicolumn{7}{|c|}{ Mechanical properties in the rolling direction } \\
\hline \multicolumn{3}{|c|}{$\mathrm{R}_{\mathrm{m}}, \mathrm{MPa}$} & $\mathrm{R}_{0.2}, \mathrm{MPa}$ & \multicolumn{3}{c|}{$\mathrm{A} \%$} \\
\hline & $459-466$ & \multicolumn{3}{c|}{$21,5-24,7$} \\
\hline
\end{tabular}

The specimens were cut in the rolling direction of sheets with a thickness of $3 \mathrm{~mm}$ and its size was plotted in Figure 1.

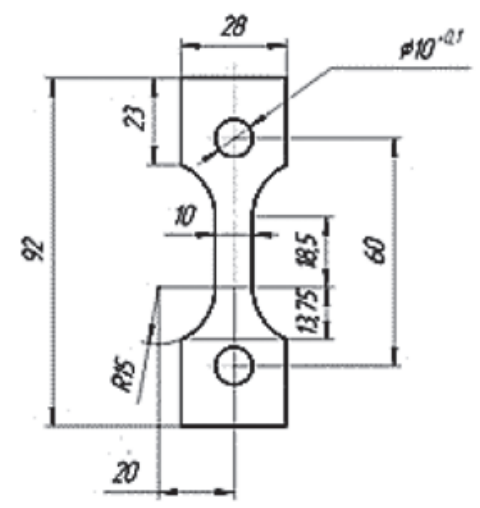

Fig.1. Geometry of specimen.

Research of the effect of additional force impulse was performed using a hydraulic machine ZD-100Pu equipped with a mechanical system to achieve additional force impulse, as described in [9]. A general view of the test stand shown in Figure 2.

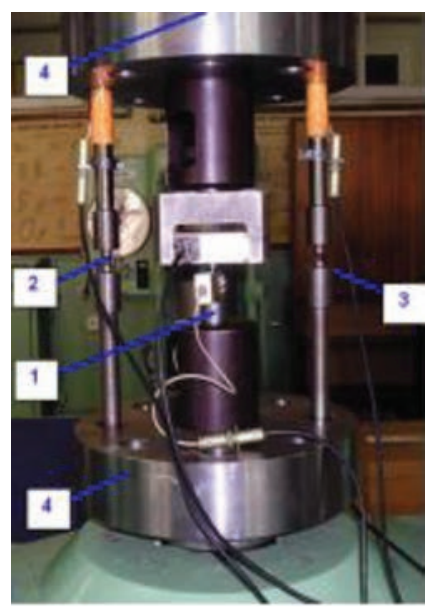

Fig.2. Setup to application additional force impulse; test specimen (1), brittle specimens (2),

torque rods (3), and mounting flanges (4).

Detailed methods and test conditions are presented in the work [10]. Additional force impulse was executed in the inelastic range stress-strain diagram.

Flat samples of 2024-T3 aluminum alloy with a cross section of $3 \times 10 \mathrm{~mm}$ was investigated. After realization of the combined load on the elastic section of the deformation, the samples were removed from the experimental setup and immediately specimens for the microscopic examination. Cylindrical rollers with a diameter of $3 \mathrm{~mm}$ for the manufacture of thin foils, were cut from the working part of the sample on an electric spark cutter. Thin foils were manufactured by electrolytic polishing and researched on a Hitachi STEM HD2700 transmission microscope. 


\section{Discussion and Results}

Table 2 gives conditions and results of the pulsed impact on deformation of specimens of aluminum alloy 2024-T3. As seen from Fig. 2-4 and Table 2, application of the pulsed impact in a rather narrow range of preliminary static deformation (0.51-0.71\%), followed by "freezing" of the newly formed dissipative structure in liquid nitrogen, may lead to a marked change in ductile properties of the alloy during subsequent static tension [11].

Conditions and results of impact on deformation of specimens of aluminum alloy 2024-T3

\begin{tabular}{|c|c|c|c|c|c|}
\hline Specimen no. & $\begin{array}{c}\sigma, \text { MPa, at the } \\
\text { moment of im- } \\
\text { pact }\end{array}$ & $\begin{array}{c}\text { Deformation } \\
\text { before impact, } \\
\varepsilon_{0} \%\end{array}$ & $\begin{array}{c}\text { Deformation to } \\
\text { fracture, } \varepsilon \%\end{array}$ & $\begin{array}{c}\text { Non-stationary } \\
\text { deformation, } \\
\dot{\varepsilon} \%\end{array}$ & $\mathrm{~F}_{\text {imp }}, \mathrm{kN}$ \\
\hline 1 & 334,67 & 0,71 & 15,75 & 11,32 & 111,86 \\
\hline 2 & 275,10 & 0,51 & 16,10 & 1,0 & 90,40 \\
\hline 3 & 328,15 & 0,64 & 26,05 & 1,07 & 99,07 \\
\hline 4 & static & & 25,87 & static & \\
\hline
\end{tabular}

The impact applied at a value close to yield stress (specimens 2 and 3) leads to an insignificant weakening of the material (compared to static tension) and a low value of nonstationary deformation.

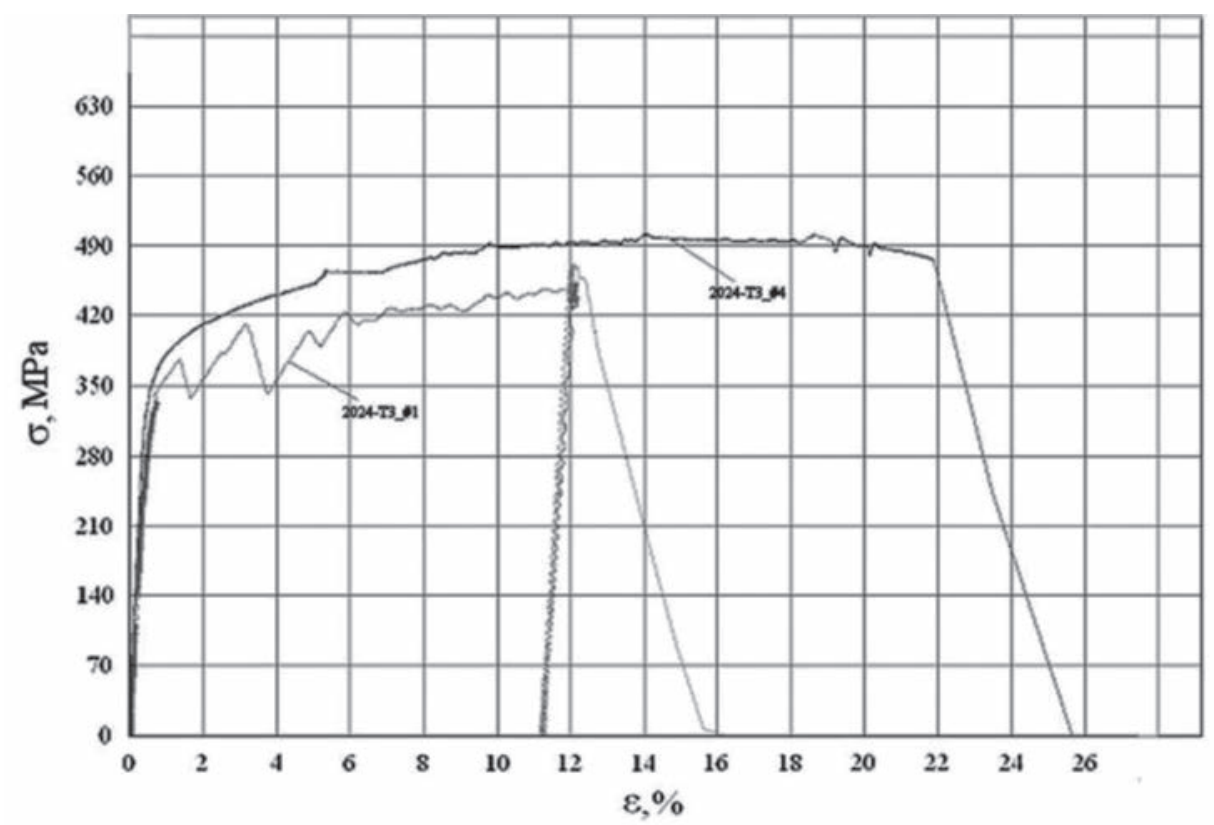

Fig.3. Results of tests of specimen 1 under complex loading conditions, and of specimen 4 in static tension [11].

Deformation to fracture for specimen 3 almost coincided with deformation in static tension, whereas a much lower value of $\mathrm{e} \%$ for specimen 2 was most probably caused by structural heterogeneity of the alloy. Even an insignificant increase in $r$ (compare specimen 3 with specimen 1) leads to a qualitative change in mechanical behavior of the material. First, specimen 1 after the impact exhibited a more substantial weakening and an extensive nonstationary deformation. At the same time, the total deformation to fracture was much lower than in static tension and in specimen 3. It is likely that the deformation to fracture in the structurally heterogeneous alloy is more a function of structural heterogeneity than a function of the s value. Interestingly enough, the non-stationary deformation of the material may differ by more than an order of magnitude depending on the s value Table 1 , whereas duration of this deformation (in real time) remains almost unchanged and equal to about $0.1-0.2 \mathrm{~s}$. Table 2 gives the most characteristic examples of the curves of strengthening in dynamic tension for alloy 2024-T3. It can be concluded from the results of the experiments that even an insignificant increase in $r$ above the yield stress value always led to growth of the nonstationary deformation and weakening, whereas the total deformation to fracture varied within $16-26 \%$. At the same 
time, in tests of many specimens the total deformation to fracture in static tension was almost constant and close to $26 \%$. This brings up a natural question: why the effect of structural heterogeneity on total deformation to fracture is detected only in dynamic tension and is not fixed in static tension. It is likely that this effect is associated with behavior of a nonlinear system at an abrupt change of external parameters $[12,13]$. Results of mechanical tests are shown in Fig. 3-5. As follows from Fig. 3 and 4, as well as from Table 2, the plastic deformation in specimens 2 and 3 was too low by the moment of the impact, i.e., the impact was applied practically in an elastic region.

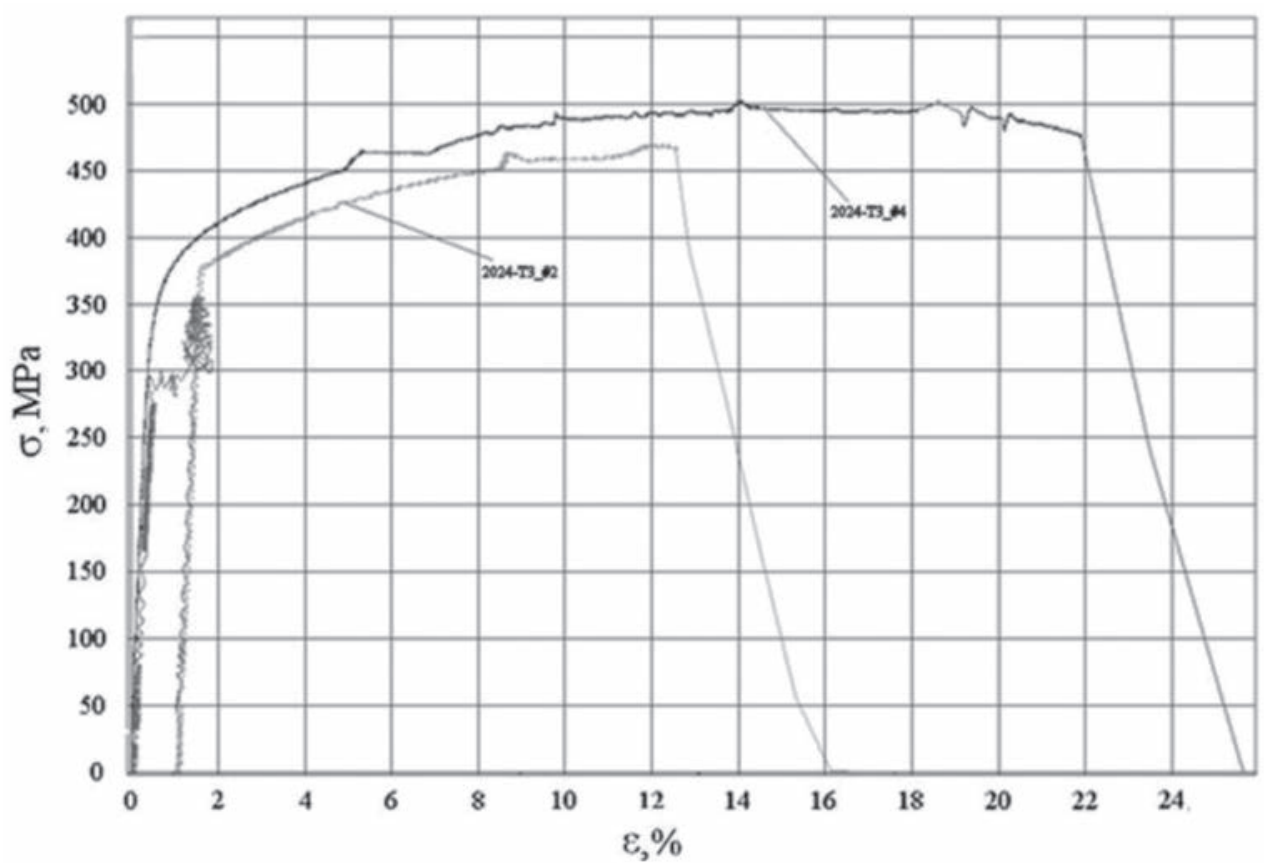

Fig.4. Results of tests of specimen 2 under complex loading conditions, and of specimen 4 in static tension [11].

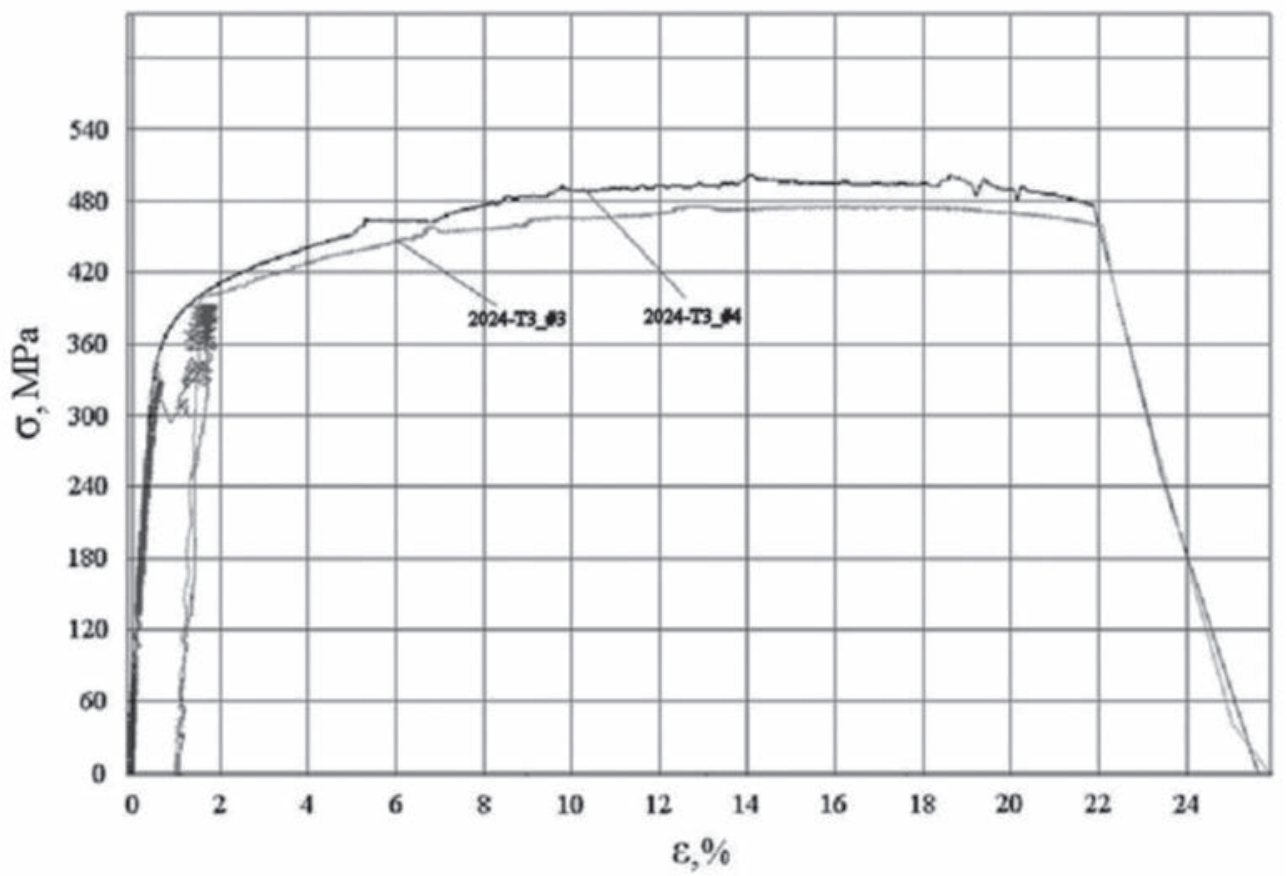

Fig.5 Results of tests of specimen 3 under complex loading conditions, and of specimen 4 in static tension [11].

It means that the crystalline structure defects, which move, multiply and interact during the plastic deformation process, were in a state close to the initial one by the moment of the impact. Therefore, only the chemical and phase composition of the alloy could experience the synergetic effects (self-organization). Most probably, the impact led to 
coagulation of precipitates of the second phase due to depletion of oversaturated solid solution. Volumetric distribution and sizes of these precipitates are responsible for the value of total deformation in the process of static tension under repeated loading after the impact and cooling in liquid nitrogen.

It is likely that in specimen 1 , because of its low but tangible plastic deformation by the moment of the impact, self-organization of the crystalline structure defects, along with coagulation of the precipitates, took place to form the hydrodynamic plastic flow channels [14]. It led to plastification of the alloy in the process of non-stationary deformation, causing a simultaneous substantial increase in the latter. Despite the almost instantaneous fracture of specimen 1 under subsequent (after the impact and holding in nitrogen) static loading, TEM examinations of structure of fractured specimen 1 revealed traces of the plastic flow channels (see below). Most probably, such channels in specimens 2 and 3 formed in the process of static tension after the impact and holding in nitrogen. It is notable that the mechanical behavior under dynamic loading of a large number of specimens we investigated (not less than 30 specimens) was equivalent to the above-described behavior of specimens 1,2 , and 3, and was determined by the fact in which region, i.e., elastic or plastic, the impact was applied.

Electron microscopic studies of the foil revealed in the aluminum matrix the inclusion of particles of the second phase, which form a well-marked contrast of the image - dark inclusions on the background of a light matrix. The particles of the second phase are evenly distributed in the volume of the grains. The predominant location of particles at the grain boundaries or subgrains was not detected. Particles of the second phase can be interpreted as dispersed allocations of $\mathrm{Al} 2 \mathrm{Cu}$ and intermetallics of $\mathrm{Al} 2(\mathrm{Cu}, \mathrm{Mg}, \mathrm{Si}, \mathrm{Fe}, \mathrm{Mn})$ [15].

Particles of round and slightly elongated shape with a size of 100-200 Nm. No significant elongation of the particles in the direction of rolling was detected (Fig. 6a, b).

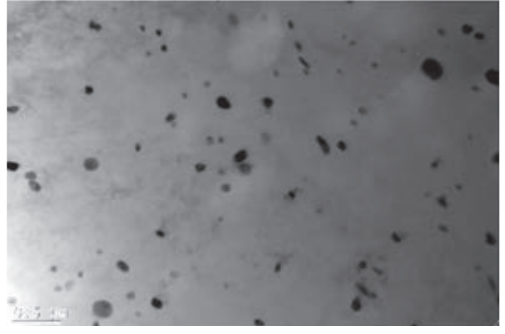

a

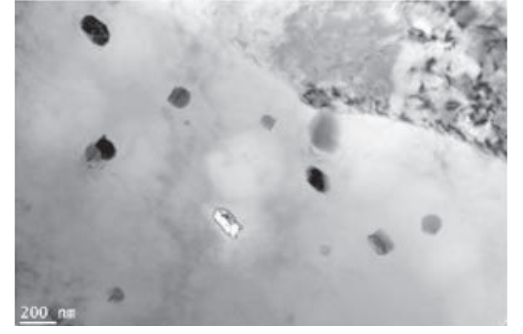

b

Fig.6. Examples of TEM structure materials in origin state (specimen without load): a- local area;

b- area nearly grain border.

After testing (specimen 3) and (specimen 4), the particles retain their shape and concentration in the aluminum matrix. No cracking or dissolution (disintegration) of dispersed secretions after testing (Fig. 6 c, d). The dislocation microstructure in the initial state of the aluminum alloy is characterized by a homogeneous grid structure (Fig. 7a). The distribution of the dislocation grid in the volume of grains, at the boundaries and near the inclusions is uniform. After the tests (specimen 3) and (specimen 4), the density of the grid dislocation structure increases (Fig. 7 b).

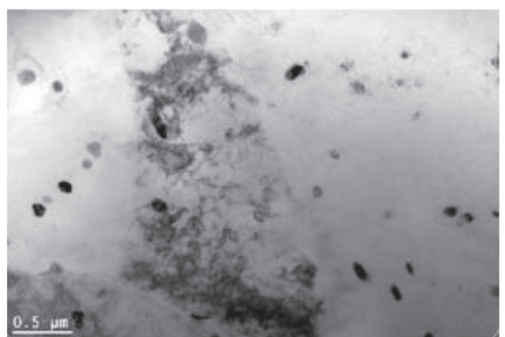

$\mathbf{a}$

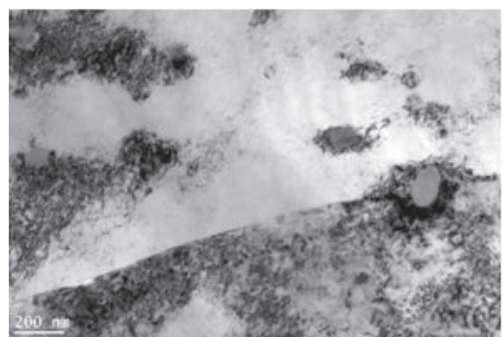

b

Fig.7. Examples of TEM structure in specimens: a- microstructure in the initial state of the aluminum alloy; $\mathrm{b}-$ microstructure under complex loading conditions.

The scalar density of dislocations $\rho$ was calculated by the intercept method, as the number $n$ of points of 
intersection of dislocations with random intercept total length L0, in foil thickness s [15]:

$$
\rho=\frac{2 n}{L_{0} s}
$$

In the initial state material, the scalar density of dislocations is approximately $\rho=1,0=10^{14} \mathrm{~m}^{-2}$. In deformed specimens, after the test (specimen 3) the scalar density of dislocations is approximately $\rho=2,0 \cdot 10^{14} \mathrm{~m}^{-2}$; after the test (specimen 4) the scalar density of dislocations is approximately $\rho=2,5 \cdot 10^{14} \mathrm{~m}^{-2}$.

The increase in the scalar density of dislocations is primarily due to a decrease in the pitch of the dislocation grid. The still significant density of the initial state of the material is explained by the fact that the aluminum alloy 2024 is thermally hardened, and in the state of supply T3 the alloy is hardened, with a high density of dislocations, to provide the necessary mechanical properties.

The increase in the density of dislocations after (specimen 4) is explained by the deformation hardening, when the density of dislocations increases during plastic deformation [16].

The change in the dislocation density after (specimen 3) is the most interesting point, because the scalar dislocation density in the material in this case is less than after the test (specimen 4), despite the same residual plastic deformation of the specimens.

The lower scalar density of dislocations when tension after a pulse, compared to tension, is due to the effect of the pulse, which obviously in some way affects the dislocation structure, changing the dislocation structure, possibly increasing the number of dislocations of one sign or the number of dislocations which provides further plastic deformation with fewer dislocations.

The presence of excess density of dislocations $\rho \pm$ in the aluminum alloy 2024-T3, ie dislocations of one sign, was determined by studying the contours of extinction [17].

In the initial state material, the contours of extinction are almost uniform within the subgrains, which indicates the equilibrium state of the dislocation structure, low internal stresses within the subgrains and, accordingly, the absence of accumulation of dislocations of one sign (Fig. 8 a, b).

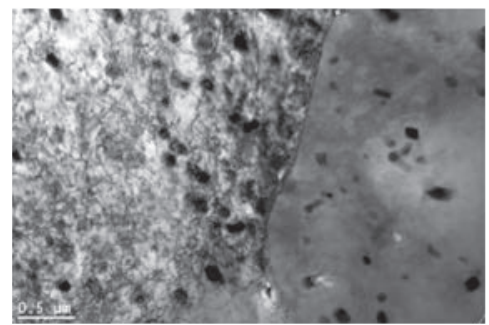

a

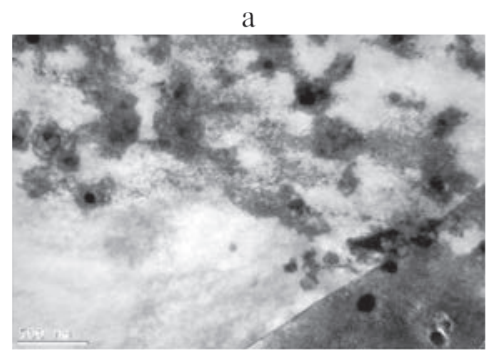

$\mathrm{c}$

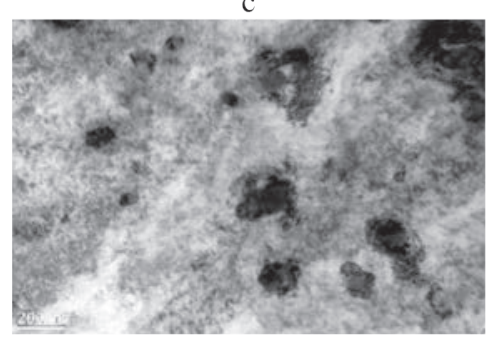

e

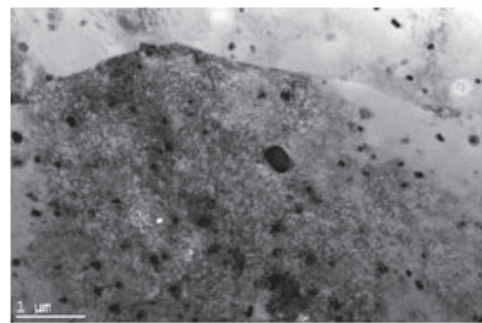

b

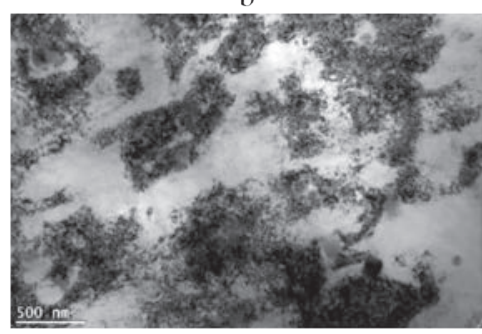

d

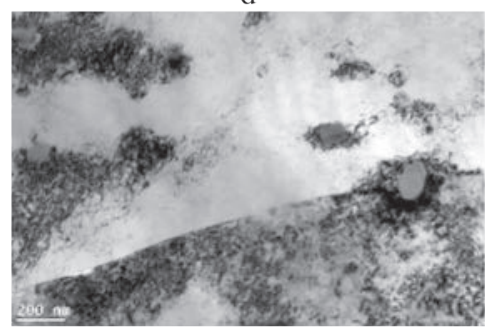

f

Fig. 8. Examples of TEM structure in specimens:

$\mathrm{a}, \mathrm{b}$ - microstructure in the initial state of the aluminum alloy;

c, e- microstructure after static loading (specimen 4);

$\mathrm{d}, \mathrm{f}-$ microstructure under complex loading conditions (specimen 3 ). 
In the presence of excessive density of dislocations of one sign, the contours of extinction form lines, the shape of which repeats the contours of dislocation cells, which means local bending of foil within each dislocation cell due to accumulation in the walls of dislocation cells dislocation charges - clusters of dislocations of one sign [17]. The presence of numerous extinction circuits inside the grains indicates high internal stresses.

In the deformed samples after tests (specimen 3) and (specimen 4) a significant number of extinction contours within the subgrains was detected, which indicates the local bending of the foil caused by the accumulation of dislocations of one sign and high internal stresses in the material microstructure (Fig. $8 \mathrm{c}$, e). Also, separate extinction contours were found in the vicinity of dispersed inclusions, which means the accumulation of internal stresses near the dispersed inclusions due to the accumulation of dislocation charges on the inclusions (Fig. $8 \mathrm{~d}, \mathrm{f}$ ).

\section{Conclusions}

The following results, were obtained from our investigation:

- The article gives results of the experimental study of mechanical properties and structure of the fractured specimens of multiphase aluminum-base alloy 2024-T3, which were deformed under the dynamic tension conditions. The specific feature of loading of the specimens consisted in the fact that the applied stress (impact) was abruptly increased at a value close to yield stress of the alloy.

- The study shows that the impact in an elastic region leads to an insignificant non-stationary deformation (i.e., deformation in the impact application process) and an insignificant weakening of the material (compared to static tension), whereas in the presence of the appreciable plastic deformation before the impact the non-stationary deformation increases more than by an order of magnitude, and a marked weakening takes place.

- a smaller scalar density of dislocations when stretching after an impulse, compared to normal stretching, due to the effect of the impulse, which obviously has a certain influence on the dislocation structure, changing the dislocation structure, possibly increasing the number of dislocations of identical potential or the number of dislocations in sub-boundaries, also possibly releases dislocations that particle affixed, which provides further plastic deformation with fewer dislocations;

- in the material of the initial state, the concentrated ring pattern are practically uniform within the subgrains, which indicates the equilibrium state of the dislocation structure, small internal stresses within the sub-grains and, accordingly, no accumulation of identical potential dislocations;

- in deformed specimens after combined loading and stretching, a significant number of concentrated ring pattern were detected within the sub-grains, which indications to a local foil bend caused by the accumulation of identical potential dislocations and high internal stresses in the microstructure of the material. Also, individual extinction outlines are found in the vicinity of dispersed inclusions, which means an accumulation of internal stresses near dispersed inclusions due to the accumulation of dislocation charge inclusions.

\section{References}

1. Hutsaylyuk V., Śnieżek L., Torzewski J., Chausov M., Berezin V., Influence of additional force impulse at the monotonic load on the deformation of 2024-T3 aluminum alloy, 5th International Scientific Conference on Defensive Technologies, Belgrad, 2012, Serbia

2. Chausov N., Zasymchuk E., Markashov L., Vyldeman V., Turchak T., Pylypenko A., Parada V., "Features deformation plastic materials at the dynamic non-equilibrium processes" Zavodskaya Laboratory. Diagnosis of materials (75)6 (2009) 52-59.

3. Zasymchuk E., Markashov L., Turchak T., Chausov N., Pylypenko A., Paratsa V. "Features structure plastic transformation of materials in the process of shock change load" Fyzycheskaya mezomehanyka 12(2) (2009) 77-82.

4. Chausov M., Lucky Y., Pylypenko A. and other."Effect of multiple change loading on the deformation of plastic material“" Mehanika i fizyka ruynuvaynya budivelnyh materialiv i konstrukcii. Zbirnyk publikaciy. Lviv Kameniar. 2009(8) 289-298.[ in Ukrainian]

5. Chausov N., Zasymchuk E., Pylypenko A., Porohnyuk E. "Samoorhanyzatsyya structury listovych materialov pri dynamicheskich neravnovesnych procesach" Journal Tambovskoho University. - Series: Estestvennye tehnycheskye and nauki (2010) (15)3 892-894.[In Russian]

6. Zasymchuk E., Yarmatov Y. "Nabludenie in situ formirovania poverhnostnogo relefa v monokrystalnoy aluminijevoj folge v processe stesnennogo rashyarenyya" Fyzycheskaya mezomehanyka (12)3 (2009) 55-60.

7. Chausov, N. "Polnaya diagrama deformyrovanyya kak istochnik informacii information o kynetyke nakoplenia 
povrezhdeniy i treshynostoykosti materiala “ Zavodskaya Laboratory.Diagnosis of materials (70)7 (2004) $42-49$. [In Russian]

8. Hutsaylyuk V., Śnieżek L., Chausov M., Pylypenko A. „Badanie własności mechanicznych stopu aluminium 2024-T3 przy odkształceniu statycznym w warunkach obciążenia złożonego" XXIV Sympozjum Zmęczenie i Mechanika Pękania (2012) 141-151 [In Poland]

9. Chausov N., Voytyuk D., Pylypenko A., Kuzmenko A. "Setup for tests of materials with full chart failure " Problems of Strength (5) (2004) 117-123.

10. Chausov M., Pylypenko A., K. Volyanska, Hutsaylyuk V. "Property of the static deformation of aluminum alloy 2024-T3 under the conditions of complex loading" Fatigue of aircraft structures Institute of Aviation, Warsaw, Poland,2012.

11. Zasimchuk E, Markashova L., Baskova O., Turchak T., Chausov N., Hutsaylyuk V., Berezin V., 2013, Influence of Combined Loading on Microstructure and Properties of Aluminum Alloy 2024-T3, Journal of Materials Engineering And Performance, Vol. 22, Iss. 11, pp. 3421-3429.

12. H. Haken, Synergetics, Naturwissenschaften, 1980, 67(3), p 121-128

13. W. Ebeling, Formation of Structures in Irreversible Processes, Mir, 1979, 85, p 280 (in Russian)

14. E.E. Zasimchuk, L.I. Markashova, T.V. Turchak, N.G. Chausov, A.P., Pylypenko, and V.N. Paratsa, Peculiarities of Transformation of Structure of Ductile Materials in the Process of Abrupt Changes in Loading Conditions, Fizicheskaya Mezomekhanika, 2009, 12, p 77-82 (in Russian)

15. Novikov I.I. Defekty kristallicheskogo stroenija metallov. - M.: Metallurgija, 1983. - 232 s.

16. Trefilov V.I., Moiseev V.F., Pechkovskij Je.P. i dr. Deformacionnoe uprochnenie i razrushenie polikristallicheskih metallov. - Kiev: Nauk. dumka, 1989. - 256 s.

17. Tokij V.V., Konstantinova T.E., Primisler V.B., Dobrikov A.A. Elektronno-mikroskopicheskij kontrast lokal'nogo izgiba pri izmenenii ugla naklona fol'gi // Metallofizika. - 1994. - T. 16, № 3. S. 65-70. 